\title{
Characteristics of COVID-19 Cases in Central Java as the 5th Most Populous Province in Indonesia
}

\author{
Dwi Sutiningsih ${ }^{1,2^{*}}$, Nur Azizah Azzahra ${ }^{2}$, Yulianto Prabowo ${ }^{3}$, Aris Sugiharto ${ }^{3}$, Mufti \\ Agung Wibowo ${ }^{3}$, Istirochah ${ }^{3}$, Endah Sri Lestari ${ }^{3}$, Estri Aurorina ${ }^{3}$, and Eka Pratiwi \\ Maharani $^{4}$ \\ ${ }^{1}$ Department of Epidemiology and Tropical Diseases, Faculty of Public Health, Diponegoro \\ University, Jl. Prof. Soedarto, S.H., Tembalang, Semarang, Central Java, Indonesia \\ ${ }^{2}$ Master of Epidemiology, School of Postgraduate, Diponegoro University, Jl. Imam Bardjo S.H., \\ No.5 Semarang, Central Java, Indonesia \\ ${ }^{3}$ Central Java Provincial Health Office, Central Java, Indonesia \\ ${ }^{4}$ Semarang City Health Office, Central Java, Indonesia
}

\begin{abstract}
Coronavirus Disease-2019 (COVID-19) cases are still increasing, while the epidemiology data is still limited. This study's purpose is to delineate characteristics of 31,407 COVID-19 patients in Central Java. This research involved secondary data acquired from the Health Office of Central Java, which was analysed univariately. The majority of the patients were 19-44-year-old (43.57\%), females $(50.81 \%)$, and private employees $(10.53 \%)$. The most frequent symptoms were fever $(18.85 \%)$, cough $(18.19 \%)$, and shortness of breath $(13.71 \%)$. Most of the cases were from Semarang City $(17.2 \%)$, Kudus (6\%), Jepara $(6 \%)$, Demak (5.5\%), and Kendal (4.3\%), with an Incidence Rate (per 10,000) of $42.79 ; 14.53 ; 14.99 ; 14.90$; and 13.84 respectively. Furthermore, most of the patients had no transit history $(87.11 \%)$, while out of 25 of the foreign transit histories, the United States of America and China contributed 24\% and $20 \%$, sequentially. Three-fourths of the domestic transit history was in Central Java, whereas the Special Capital Region of Jakarta, South Sulawesi, and East Java shared 9.79\%, 5.99\%, and 3.08\%. The most common transit history in Central Java was in Semarang City (19.28\%) and Kudus (13.91\%). In conclusion, the characteristics of COVID-19 cases were varied, and local transmission has occurred, which has spread to 35 cities/districts.
\end{abstract}

\section{Introduction}

Coronavirus Disease-2019 (COVID-19) was first recognized in December 2019 in Wuhan City, Hubei Province, China [1]. COVID-19, formerly known as 2019-nCoV, was announced as a Public Health Emergency of International Concern on 30 January 2020 and a pandemic on 11 March 2020 by the WHO [2]. As of 21 October 2020, the cumulative

* Corresponding author: dwi.sutiningsih@live.undip.ac.id 
COVID-19 cases reported in 235 countries, regions, or territories were 40,455,651 cases, including 1,119,431 deaths [3], while the number of cases in Southeast Asia was 8,610,317 cases [4].

The first reported COVID-19 case in Indonesia was on 2 March 2020 [5]. On 31 March 2020, the Indonesian Government designated COVID-19 as a type of disease that causes a Public Health Emergency [6] and, on 13 April 2020, a national disaster based on Presidential Decree 12 of 2020 [7]. As of 21 October 2020, there were 373,109 cumulative cases of COVID-19 in Indonesia, which were spread across 34 provinces. Meanwhile, Central Java Province ranked 4th of the cumulative COVID-19 cases [8]. One of the probable reasons is because Central Java Province has the 5th most populous population with $1058 / \mathrm{km} 2$ in 2019 based on the Central Statistics Agency of Indonesia [9]. The research conducted in Europe showed that inhabitants' density was associated with the COVID-19 spreads [10]. In a study conducted in all Algerian cities, COVID-19 cases increased along with increasing population density by one individual $/ \mathrm{km} 2$, an increase estimated at 0.48 [11].

Before this study, an article related to the characteristics and travel history of COVID19 cases in Central Java. However, the case data collected from 3 March 2020 to 3 June 2020 were only 1533 respondents [12]. Due to the increase in cases to date, analysis of more frequency is required. This research aims to provide patient characteristics, occupational distribution, symptoms, case distribution in each district/city, and travel transit history in Central Java involving 31,407 cases.

\section{Method}

A descriptive study was used in this research involving secondary data from data reports of COVID-19 patients, as many as 31,407 cases, at the Central Java Provincial Health Office up to 21 October 2020. The collected data were demographic information (age, gender, occupation, district) and transit history. In the first stage, the data was processed through editing, coding, cleaning, and tabulating stages.

\section{Editing stage}

Editing was carried out on the data obtained from the recording by the Central Java Provincial Health Office. Initially, there was a general condition variable but then combined into a single variable, symptoms, because many data on that variable stated the patients' symptoms. The patient's transit location names (country, district, or city) recorded in the transit variable were edited only to write the name of the city, district, or country visited without any other information.

\section{Coding stage}

Coding was used to convert the original data, which was letters, to numerical data. Its objective was to simplify data in order to make processing and analysis easier. Age and gender variables were coded.

\section{Cleaning}

The cleaning stage was used to verify the data entered into the data processing application to identify missing data and data variations. This was accomplished by creating a frequency distribution table for each variable and then examining its frequency.

\section{Tabulating}

In this stage, the data were classified according to the purpose. Tabulation in this 
analysis was done by tabulating the frequency.

After processing the data, the next step was analyzing the data through univariate analysis and presented in tables. After the data was displayed, a discussion was carried out about the frequency distribution.

\section{Results}

\subsection{Characteristics of COVID-19 patients in Central Java}

Table 1 shows that the adult age group (19-44 years) had the greatest percentage $(43.57 \%)$ among the others, followed by pre-elderly (45-59 years) with $30.97 \%$. Meanwhile, the least was in the infant group ( 0 years) with $0.81 \%$. The average age of COVID-19 patients was 41 years. The case distribution between gender categories was almost the same, in which the percentage of males $(49.19 \%)$ was slightly lower than the female group $(50.81 \%)$. Most patients have an unknown occupation with $44.35 \%$. Also, private employees had the highest percentage with $10.53 \%$ of the respondents with known works, while health workers contributed 3.95\%. The most prevalent symptoms of COVID-19 patients were fever $(18.85 \%)$, cough $(18.19 \%)$, and shortness of breath $(13.71 \%)$. Meanwhile, the others were limp (5.32\%), nausea $(4.86 \%)$, cold $(3.28 \%)$, headache $(2.67 \%)$, diarrhea $(1.19 \%)$, shivering $(0.22 \%)$, vomiting $(1.91 \%)$, stomach pain $(1.72 \%)$, sore throat $(2.62 \%)$, and muscle cramps $(0.05 \%)$, and so forth $(2.22 \%)$. Furthermore, there was $62.70 \%$ from 31,407 cases with not filled symptom data.

Table 1. Characteristics of COVID-19 Patients in Central Java.

\begin{tabular}{|l|c|c|}
\hline Patient Characteristics & $\begin{array}{c}\text { Frequency } \\
\text { (F= 31,407) }\end{array}$ & $\mathbf{\%}$ \\
\hline Age & & \\
\hline$\geq 60$ years (elderly) & 4713 & $15.01 \%$ \\
\hline 45-59 years (pre-elderly) & 9727 & $30.97 \%$ \\
\hline $\mathbf{1 9 - 4 4}$ years (Adult) & $\mathbf{1 3 , 6 8 5}$ & $\mathbf{4 3 . 5 7 \%}$ \\
\hline 10-18 years (Youth) & 2122 & $6.76 \%$ \\
\hline 6-9 years (Children) & 398 & $1.27 \%$ \\
\hline 1-5 years (toddlers) & 507 & $1.61 \%$ \\
\hline 0 years (Infant) & 255 & $0.81 \%$ \\
\hline Gender & & \\
Male & 15,450 & $49.19 \%$ \\
Female & $\mathbf{1 5 , 9 5 7}$ & $\mathbf{5 0 . 8 1 \%}$ \\
\hline Job & & \\
\hline Employees of Regional/State Owned & 211 & 0.67 \\
\hline Enterprises & & 1.23 \\
\hline Police/Army & 386 & 1.06 \\
\hline Freelance & 333 & 1.09 \\
\hline Retired & 342 & 1.23 \\
\hline Teacher & 386 & 2.42 \\
\hline Farmer/ Agriculture Sector & 760 & 2.34 \\
\hline Traders & 735 & 3.57 \\
\hline Civil Servant & 1122 & 3.95 \\
\hline Health workers & 1240 & 6.00 \\
\hline Unemployment & 1885 & 6.06 \\
\hline Minding Household & 1904 & 6.67 \\
\hline Student & 2096 & $\mathbf{1 0 . 5 3}$ \\
\hline Entrepreneur & 2169 & \\
\hline Private employees & $\mathbf{3 3 0 6}$ & \\
\hline
\end{tabular}




\begin{tabular}{|l|c|c|}
\hline Etc. & 602 & 1.92 \\
\hline Unknown & 13,930 & 44.35 \\
\hline Symptom & & \\
\hline Cough & $\mathbf{5 7 1 3 / 3 1 , 4 0 7}$ & $\mathbf{1 8 . 1 9}$ \\
\hline Cold & $1030 / 31,407$ & 3.28 \\
\hline Fever & $\mathbf{5 9 1 9 / 3 1 , 4 0 7}$ & $\mathbf{1 8 . 8 5}$ \\
\hline Shortness of breath & $\mathbf{4 3 0 5 / 3 1 , 4 0 7}$ & $\mathbf{1 3 . 7 1}$ \\
\hline Limp & $1671 / 31,407$ & 5.32 \\
\hline Nausea & $1527 / 31,407$ & 4.86 \\
\hline Headache & $840 / 31,407$ & 2.67 \\
\hline Diarrhea & $375 / 31,407$ & 1.19 \\
\hline Shivering & $68 / 31,407$ & 0.22 \\
\hline Vomiting & $601 / 31,407$ & 1.91 \\
\hline Stomach pain & $539 / 31,407$ & 1.72 \\
\hline Sore throat & $822 / 31,407$ & 2.62 \\
\hline Muscle Cramps & $17 / 31,407$ & 0.05 \\
\hline Etc. & $696 / 31,407$ & 2.22 \\
\hline Not Filled & $19,692 / 31,407$ & 62.70 \\
\hline \multicolumn{2}{|l}{} \\
\hline
\end{tabular}

\subsection{Distribution of COVID-19 Cases based on District / City in Central Java Province}

Based on Table 2, the most excellent Incidence Rate or IR / 10,000 figure estimate in Central Java was in Semarang City with 42.79, which means that for every 10,000 populations of Semarang City, there were 42-43 COVID-19 cases. Apart from that, Semarang City also had the most significant percentage of COVID-19 cases, with $17.2 \%$, accompanied by Kudus (6\%), Jepara (6\%), Demak (5.5\%), and Kendal (4.3\%), with Incidence Rate or IR (per 10,000) 14.53; 14.99; 14.90; and 13.84 sequentially.

Table 2. Frequency of COVID-19 Cases in Each District / City in Central Java Province.

\begin{tabular}{|l|l|l|c|c|}
\hline District/City & $\begin{array}{l}\text { Frequency } \\
(\mathbf{F})\end{array}$ & $\mathbf{\%}$ & $\begin{array}{c}\text { Total } \\
\text { population* }\end{array}$ & IR/10,000 \\
\hline Semarang City & $\mathbf{5 , 3 9 0}$ & $\mathbf{1 7 . 2}$ & $\mathbf{1 , 2 5 9 , 5 9 0}$ & $\mathbf{4 2 . 7 9}$ \\
\hline Kudus & $\mathbf{1 , 8 9 3}$ & $\mathbf{6 . 0}$ & $\mathbf{1 , 3 0 2 , 8 1 3}$ & $\mathbf{1 4 . 5 3}$ \\
\hline Jepara & $\mathbf{1 , 8 8 5}$ & $\mathbf{6 . 0}$ & $\mathbf{1 , 2 5 7 , 9 1 2}$ & $\mathbf{1 4 . 9 9}$ \\
\hline Demak & $\mathbf{1 , 7 3 2}$ & $\mathbf{5 . 5}$ & $\mathbf{1 , 1 6 2 , 8 0 5}$ & $\mathbf{1 4 . 9 0}$ \\
\hline Kendal & $\mathbf{1 , 3 4 4}$ & $\mathbf{4 . 3}$ & $\mathbf{9 7 1 , 0 8 6}$ & $\mathbf{1 3 . 8 4}$ \\
\hline Semarang & 1,149 & 3.7 & 891,912 & 12.88 \\
\hline Kebumen & 1,109 & 3.5 & $1,197,982$ & 9.26 \\
\hline Wonosobo & 1,068 & 3.4 & 790,504 & 13.51 \\
\hline Boyolali & 995 & 3.2 & 984,807 & 10.10 \\
\hline Sukoharjo & 918 & 2.9 & $1,440,698$ & 6.37 \\
\hline Magelang & 886 & 2.8 & 933,989 & 9.49 \\
\hline Klaten & 795 & 2.5 & $1,174,986$ & 6.77 \\
\hline Rembang & 757 & 2.4 & 890,518 & 8.50 \\
\hline Cilacap & 729 & 2.3 & $1,727,098$ & 4.22 \\
\hline Sragen & 716 & 2.3 & 519,587 & 13.78 \\
\hline Purworejo & 697 & 2.2 & $1,814,110$ & 3.84 \\
\hline
\end{tabular}




\begin{tabular}{|l|l|l|c|c|}
\hline Surakarta City & 684 & 2.2 & 897,711 & 7.62 \\
\hline Temanggung & 670 & 2.1 & 772,018 & 8.68 \\
\hline Karanganyar & 669 & 2.1 & 886,519 & 7.55 \\
\hline Blora & 624 & 2.0 & 865,013 & 7.21 \\
\hline Pati & 614 & 2.0 & 718,316 & 8.55 \\
\hline Banyumas & 611 & 1.9 & $1,693,006$ & 3.61 \\
\hline Tegal & 570 & 1.8 & 249,905 & 22.81 \\
\hline Grobogan & 569 & 1.8 & $1,377,788$ & 4.13 \\
\hline Batang & 553 & 1.8 & 768,583 & 7.20 \\
\hline Pemalang & 496 & 1.6 & 194,084 & 25.56 \\
\hline Brebes & 474 & 1.5 & $1,809,096$ & 2.62 \\
\hline Pekalongan & 337 & 1.1 & 638,188 & 5.28 \\
\hline Banjarnegara & 310 & 1.0 & 923,192 & 3.36 \\
\hline Pekalongan City & 291 & 0.9 & $1,290,591$ & 2.25 \\
\hline Tegal City & 256 & 0.8 & 307,097 & 8.34 \\
\hline Wonogiri & 251 & 0.8 & 959,492 & 2.62 \\
\hline Purbalingga & 245 & 0.8 & $1,053,786$ & 2.32 \\
\hline Magelang City & 241 & 0.8 & 871,311 & 2.77 \\
\hline Salatiga City & 230 & 0.7 & 122,111 & 18.84 \\
\hline Etc (Unknown) & 649 & 2.1 & & \\
\hline & 31.407 & 100 & & \\
\hline Total & & & & \\
\hline
\end{tabular}

* Central Java Provincial Statistics Agency Data in 2019

IR or Incidence Rate

\subsection{COVID-19 Patients' Transit History}

The majority of COVID-19 cases had no history of travel transit (87.11\%) (Table 3). Meanwhile, the most reported cases had domestic transit history (12.81\%), whereas 24 patients had foreign transit history with $0.08 \%$. The majority of foreign transit was from the United States of America and China, sequentially with 6 cases and 5 cases. Meanwhile, the other countries were Japan, Malaysia, Singapore, Qatar, Brazil, India, Turkey, Papua New Guinea, Vietnam, Netherlands and the Philippines.

Table 3. Frequency distribution of COVID-19 patients' transit history.

\begin{tabular}{|l|c|c|}
\hline Transit History & Frequency (F) & $\mathbf{\%}$ \\
\hline No history & $27,359 / 31,407$ & 87.11 \\
\hline History of Domestic Transit & $4023 / 31,407$ & 12.81 \\
\hline In Province of Central Java & $3011 / 31,407$ & 9.59 \\
\hline In Other Provinces & $1005 / 31,407$ & 3.20 \\
\hline In Central Java Province and From Other Provinces & $7 / 31,407$ & 0.02 \\
\hline History of Domestic (in Central Java) and Foreign Transit & $1 / 31,407$ & 0.00 \\
\hline History of Foreign Transit & $24 / 31,407$ & 0.08 \\
\hline Japan & $1 / 25$ & 4.00 \\
\hline China & $5 / 25$ & 20.00 \\
\hline Malaysia & $2 / 25$ & 8.00 \\
\hline Singapore & $3 / 25$ & 12.00 \\
\hline Qatar & $1 / 25$ & 4.00 \\
\hline Brazil & $2 / 25$ & 8.00 \\
\hline
\end{tabular}




\begin{tabular}{|l|c|c|}
\hline India & $3 / 25$ & 12.00 \\
\hline United States of America & $6 / 25$ & 24.00 \\
\hline Turkey & $1 / 25$ & 4.00 \\
\hline Papua New Guinea & $2 / 25$ & 8.00 \\
\hline Vietnam & $1 / 25$ & 4.00 \\
\hline Netherlands & $1 / 25$ & 4.00 \\
\hline Philippines & $1 / 25$ & 4.00 \\
\hline
\end{tabular}

According to Table 4, three-fourth of domestic transit history was in Central Java. The other provinces which shared the higher percentage of domestic transit history were the Special Capital Region of Jakarta (9.79\%), South Sulawesi (5.99\%), and East Java $(3.08 \%)$.

Table 4. COVID-19 Distribution based on domestic transit in 34 Provinces in Indonesia.

\begin{tabular}{|l|c|c|}
\hline Province & $\begin{array}{c}\text { Frequency } \\
(\mathbf{F}=\mathbf{4 , 0 2 4})\end{array}$ & $\mathbf{\%}$ \\
\hline$>1$ Transit Places & $54 / 4,024$ & 1.34 \\
\hline Aceh & $1 / 4,024$ & 0.02 \\
\hline North Sumatera & $8 / 4,024$ & 0.20 \\
\hline West Sumatera & $2 / 4,024$ & 0.05 \\
\hline Riau & $6 / 4,024$ & 0.15 \\
\hline Jambi & $1 / 4,024$ & 0.02 \\
\hline South Sumatera & $7 / 4,024$ & 0.17 \\
\hline Bengkulu & $0 / 4,024$ & 0.00 \\
\hline Lampung & $3 / 4,024$ & 0.07 \\
\hline Bangka Belitung Islands & $0 / 4,024$ & 0.00 \\
\hline Riau islands & $3 / 4,024$ & 0.07 \\
\hline Special Capital Region of Jakarta & $394 / 4,024$ & 9.79 \\
\hline West Java & $98 / 4,024$ & 2.44 \\
\hline Central Java & $3019 / 4,024$ & 75.02 \\
\hline Special Region of Yogyakarta & $55 / 4,024$ & 1.37 \\
\hline East Java & $124 / 4,024$ & 3.08 \\
\hline Banten & $22 / 4,024$ & 0.55 \\
\hline Bali & $8 / 4,024$ & 0.20 \\
\hline West Nusa Tenggara & $3 / 4,024$ & 0.07 \\
\hline East Nusa Tenggara & $0 / 4,024$ & 0.00 \\
\hline West Kalimantan & $1 / 4,024$ & 0.02 \\
\hline Central Kalimantan & $1 / 4,024$ & 0.02 \\
\hline South Kalimantan & $7 / 4,024$ & 0.17 \\
\hline East Kalimantan & $20 / 4,024$ & 0.50 \\
\hline North Kalimantan & $12 / 4,024$ & 0.30 \\
\hline North Sulawesi & $3 / 4,024$ & 0.07 \\
\hline Central Sulawesi & $3 / 4,024$ & 0.07 \\
\hline South Sulawesi & $241 / 4,024$ & 5.99 \\
\hline Southeast Sulawesi & $2 / 4,024$ & 0.05 \\
\hline Gorontalo & $0 / 4,024$ & 0.00 \\
\hline West Sulawesi & $0 / 4,024$ & 0.00 \\
\hline Maluku & $4 / 4,024$ & 0.10 \\
\hline North Maluku & $5 / 4,024$ & 0.12 \\
\hline Papua & $4 / 4,024$ & 0.10 \\
\hline West Papua & $2 / 4,024$ & 0.05 \\
\hline & & \\
\hline & & \\
\hline
\end{tabular}

The most-reported transit history in Central Java was in Semarang City (19.28\%) and Kudus District (13.91\%), shown in Table 5. 
Table 5. COVID-19 Distribution based on Domestic Transit inside Province of Central Java.

\begin{tabular}{|l|c|c|}
\hline Travel History inside Province of Central Java & $\begin{array}{c}\text { Frequency } \\
\text { (F=3,019) }\end{array}$ & $\mathbf{\%}$ \\
\hline$>1$ Transit Places & $32 / 3019$ & 1.06 \\
\hline Semarang City & $582 / 3,019$ & 19.28 \\
\hline Kudus & $420 / 3,019$ & 13.91 \\
\hline Jepara & $90 / 3,019$ & 2.98 \\
\hline Demak & $224 / 3,019$ & 7.42 \\
\hline Kendal & $16 / 3,019$ & 0.53 \\
\hline Semarang & $156 / 3,019$ & 5.17 \\
\hline Kebumen & $61 / 3,019$ & 2.02 \\
\hline Wonosobo & $182 / 3,019$ & 6.03 \\
\hline Boyolali & $41 / 3,019$ & 1.36 \\
\hline Sukoharjo & $76 / 3,019$ & 2.52 \\
\hline Magelang & $28 / 3,019$ & 0.93 \\
\hline Klaten & $51 / 3,019$ & 1.69 \\
\hline Rembang & $8 / 3,019$ & 0.26 \\
\hline Cilacap & $84 / 3,019$ & 2.78 \\
\hline Sragen & $28 / 3,019$ & 0.93 \\
\hline Purworejo & $2 / 3,019$ & 0.07 \\
\hline Surakarta City & $209 / 3,019$ & 6.92 \\
\hline Temanggung & $6 / 3,019$ & 0.20 \\
\hline Karanganyar & $86 / 3,019$ & 2.85 \\
\hline Blora & $15 / 3,019$ & 0.50 \\
\hline Pati & $87 / 3,019$ & 2.88 \\
\hline Banyumas & $170 / 3,019$ & 5.63 \\
\hline Tegal & $14 / 3,019$ & 0.46 \\
\hline Grobogan & $105 / 3,019$ & 3.48 \\
\hline Batang & $29 / 3,019$ & 0.96 \\
\hline Pemalang & $112 / 3,019$ & 3.71 \\
\hline Brebes & $33 / 3,019$ & 1.09 \\
\hline Pekalongan & $23 / 3,019$ & 0.76 \\
\hline Banjarnegara & $19 / 3,019$ & 0.63 \\
\hline Pekalongan City & $13 / 3,019$ & 0.43 \\
\hline Tegal City & $3 / 3,019$ & 0.10 \\
\hline Wonogiri & $17 / 3,019$ & 0.56 \\
\hline Purbalingga & $51 / 3,019$ & 1.69 \\
\hline Magelang City & $5 / 3,019$ & 0.17 \\
\hline Salatiga City & $9 / 3,019$ & 0.30 \\
\hline & & \\
\hline & & \\
\hline
\end{tabular}

\section{Discussion}

COVID-19 cases in Central Java were predominantly adult (19-44 years) and pre-elderly (45-59 years), while the minority aged 0 years, with an average age of 41 . This report is almost similar to Basrah Province-Southern Iraq; patients aged 20-44 and 45-59 contributed $38.82 \%$ and $31.58 \%$, respectively, while age 0 years shared $0 \%$ [13]. Besides, most of the COVID-19 patients in Central Java were female. This result is supported by studies carried in Europe, Jordan, and Korea, with percentages of females being $67.7 \%$, $54.3 \%, 54.6 \%$, sequentially [14-16]. However, this result was opposed to other studies in Oman, Iran, and China, where the majority of cases were male, with $80.3 \%$ [17], 66\% [18], and 51.4\% [19], consecutively. On the other side, this analysis identified confirmed healthcare workers (HCWs). The research in China found 1716 patients $(3.8 \%)$ working as 
health care workers [19]. HCWs have a double high-risk exposure both for themselves and spreading to others [20].

The most common COVID-19 symptoms were cough, fever, and shortness of breath. It is similar to research in China, where the most clinical features were fever $(80.55 \%)$, cough (72.86\%), and dyspnea (42.63\%) [21], in New York [22] and Korea [16]. Meanwhile, research in Iran found dry cough, anorexia, dyspnea, and fever experienced by suspected patients [23]. Among the 35 cities/ regencies in Central Java, the highest COVID 19 cases were from Semarang City. As the provincial capital city of Central Java and Metropolitan city, Semarang City has adequate transportation facilities consisting of port facilities, air transportation, ground transportation such as trains and buses [24]. This improvement leads to increasing population mobility and contributes to the COVID-19 transmission [25]. The availability of an International Airport in Semarang City, namely Ahmad Yani Airport [24], probably affects the COVID-19 spread [13]. The total cases in Semarang were followed by Kudus, Jepara, Demak, and Kendal. The reason was perhaps because of the distance between that regency capital with Semarang City as the epicentre in Central Java, $60 \mathrm{~km}, 78 \mathrm{~km}, 26 \mathrm{~km}$, and $28 \mathrm{~km}$ [26], which possibly affected peoples' mobility.

Mostly, the recorded COVID-19 patients had no transit history. This analysis is the same as a study carried in Basrah, Southern Iraq, where almost all cases had never travelled outside Basrah (96.1\%) [13]. This study proves that most of the patients were infected due to local spread in Central Java. As the highest transit histories and most cases from Semarang City and Kudus District, these zones probably were the hotspot of the COVID-19 transmission in Central Java. Besides, the Special Capital Region of Jakarta, South Sulawesi, and East Java were the most frequent transit histories from other provinces. The Capital Region of Jakarta, East Java, and South Sulawesi ranked first, second, and fifth of the highest total COVID-19 cases with 96,217; 49,474; and 17,593 cases (data up to 20 October 2020) [8].

Meanwhile, the present study reveals that the United States of America and China became the two countries with the most regular international transits. In line with the study in Korea, $75.1 \%$ of 16 index cases recorded between 20 January and 10 February 2020 were imported from China [27]. Both China and the United States of America declared their first cases before Indonesia. The case was firstly found in Wuhan City, China, on 8 December 2019 [28]. In January 2020, America announced its first cases from Wuhan, China, and returned on 15 January 2020 [29].

\section{Conclusions}

This study concludes that there were variations of the characteristics of COVID-19 patients and that local transmission has happened in Central Java. Besides, most cases have no history of transit with $87.11 \%$, while domestic transit shared a higher percentage, which is $12.81 \%$, compared to foreign transit $(0.08 \%)$. Therefore, it is necessary to strengthen the enforcement of health protocols to control the COVID-19 transmission in Central Java Province and strict guarding at the entrances to Central Java Province, including at ports, land routes, and airports, by increasing the role of relevant institutions and coordination multi-sectors. Additional study is needed to determine the variables that contribute to the spread of infection, such as density of population, geographical conditions, including climatic conditions, rainfall, and humidity levels. Due to the incomplete data, such as job characteristics and the distribution of the cases in each district/ city, it is better to record and report related to the COVID-19 patients' identity to facilitate clusters' determination and interventions. 
The authors would like to reveal our gratitude to COVID-19 workforce and all workers and volunteers who had roles in collecting the data in Central Java.

\section{References}

1. World Health Organization, COVID-19 clinical management clinical management living guidance, Geneva: World Health Organization (2021)

2. World Health Organization, Archived: WHO Timeline - COVID-19, World Health Organization, (2020) https://www.who.int/news-room/detail/27-04-2020-whotimeline---covid19?gclid=EAIaIQobChMI4MaewOeo6gIVyyMrCh2JRgUIEAAYASAAEgLo3 D B $\underline{w E}$

3. World Health Organization, Coronavirus Disease (COVID-19): Numbers at a glance. World Health Organization, (2020) Available from:

https://www.who.int/emergencies/diseases/novel-coronavirus2019? gclid=Cj0KCQjwuL 8BRCXARIsAGiC51Bg1N4gjFas7pBxtuQW1OL8qVvk2 Kvm6kZ912yWupBDcyRa85oLfbwaAt0bEALw_wcB

4. World Health Organization, WHO Coronavirus Disease (COVID-19)

Dashboard,World Health Organization, (2020) Available from: https://covid19.who.in/

5. Indonesian Minister of Health. [Decree of the Minister of Health of the Republic of Indonesia Number HK.01.07 / MenKes / 413/2020 concerning Guidelines for the Prevention and Control of Corona Virus Disease 2019 (Covid-19)] (2020)

6. President of Republic Indonesia. [Presidential Decree of the Republic of Indonesia Number 11 of 2020 concerning the Determination of the Coronavirus Disease 2019 (Covid-19) Public Health Emergency] (2020)

7. President of Republic Indonesia. [Presidential Decree No. 12 of 2020 concerning the Determination of Non-Natural Disasters of the Corona Virus Disease 2019 as a National Disaster] (2020)

8. Indonesian Ministry of Health. [Current Situation of Novel Coronavirus (Covid-19) Development Data reported until 22 October 2020] (2020)

9. The Central Bureau of Statistics, Population Density by Province (soul/km2), 2015 2019The Central Bureau of Statistics of Indonesia, (2020) Available from: https://www.bps.go.id/linkTableDinamis/view/id/960

10. R. Mogi, J. Spijker. The influence of social and economic ties to the spread of COVID-19 in Europe, 1-27 (2020) https://doi.org/10.31235/osf.io/sb8xn

11. N. Kadi, M. Khelfaoui, Population density, a factor in the spread of COVID-19 in Algeria: statistic study, Bull Natl Res Cent, 44 (138): 1-7 (2020) https://doi.org/10.1186/s42269-020-00393-X

12. D. Sutiningsih, V. E. F. Rahatina, Y. Prabowo Y, A. Haryanto, M. A. Wibowo, Epidemiologic and clinical characteristics of patients with Covid-19 in Central Java, Indonesia, E3S Web Conf. 202 (12014): 1-1 (2020) https://doi.org/10.1051/e3sconf/202020212014d

13. O. S. Habib, S. K. AlKanan, S. H. Abed, N. Q. Mohammed. RESEARCH PAPER epidemiological features of COVID-19 epidemic in Basrah Province-Southern IraqFirst report. Med. J. Basrah. Univ. 38 (1): 7-18 (2020) http://dx.doi.org/10.33762/mjbu.2020.126943.1008

14. J. R. Lechien et al. Clinical and epidemiological characteristics of 1420 European 
patients with mild-to-moderate coronavirus disease 2019. J. Intern. Med. 288 (3): 335-44 (2020) https://doi.org/10.1111/joim.13089

15. S. M. Samrah et al. COVID-19 outbreak in Jordan: Epidemiological features, clinical characteristics, and laboratory findings. Ann. Med. Surg. 57(July): 103-8 (2020) https://doi.org/10.1016/j.amsu.2020.07.020

16. H. Son et al. Epidemiological characteristics of and containment measures for COVID-19 in Busan, Korea. 42:1-8 (2020) https://doi.org/10.4178/epih.e2020035

17. F. Khamis, B. Al Rashidi, I. Al-Zakwani, A. H. Al Wahaibi, S. T. Al Awaidy. Epidemiology of COVID-19 infection in Oman: Analysis of the first 1304 cases. Oman. Med. J. 35 (3): 1-4 (2020) https://doi.org/10.5001/omj.2020.60

18. M. Nikpouraghdam et al. Epidemiological characteristics of coronavirus disease 2019 (COVID-19) patients in IRAN: A single center study. J. Clin. Virol. J. 127 (104378): 1-4 (2020) https://doi.org/10.1016/j.jcv.2020.104378

19. The Novel Coronavirus Pneumonia Emergency Response Epidemiology Team, The Epidemiological Characteristics of an Outbreak of 2019 Novel Coronavirus Diseases (COVID-19) - China, 2020. China CDC Weekly. 2 (8): 113-22 (2020) https://doi.org/10.46234/ccdcw2020.032

20. J. C. Rueda-Garrido et al. Return to work guidelines for the COVID-19 pandemic, Occup. Med (Chic Ill). 70 (5): 300-5 (2020) https://doi.org/10.1093/occmed/kqaa099

21. D. Liu et al. Risk factors for developing into critical COVID-19 patients in Wuhan, China: A multicenter, retrospective, cohort study. EClinicalMedicine. 25: 100471 (2020) https://doi.org/10.1016/j.eclinm.2020.100471

22. L. Palaiodimos et al. Severe obesity, increasing age and male sex are independently associated with worse in-hospital outcomes, and higher in-hospital mortality, in a cohort of patients with COVID-19 in the Bronx, New York. Metabolism. 108: 154262 (2020) Available from: https://www.sciencedirect.com/science/article/pii/S0026049520301268

23. A. Hosseinzadeh et al. Epidemiological patterns of syndromic symptoms in suspected patients with COVID-19 in Iran: A latent class analysis. J. Res. Health. Sci. 21 (x): 15 (2021) https://doi.org/ 10.34172/jrhs.v0i0.6262

24. The Semarang City Government, Semarang city profile, (2018) Available from: http://semarangkota.go.id/p/33/profil_kota. Indonesia.

25. Y. Haiyan, D. Guangcai, Analysis on the epidemic factors for COVID-19, Chinese. J. Prev. Med. 54 (00): E021-E021 (2020) Chinese.

26. Central Java Provincial Government, Distance between Regency/Municipality Capital and Province Capital in Jawa Tengah Province (km), 2005 - 2018. (2017) Available from: https://jateng.bps.go.id/statictable/2017/10/26/1514/jarak-dari-ibukotakabupaten-kota-ke-ibukota-provinsi-di-provinsi-jawa-tengah-km-tahun-2015--2018.html

27. K. Moran. Epidemiologic characteristics of early cases with 2019 novel coronavirus (2019- $n \mathrm{CoV})$ disease in Korea, Epidemiol. Health. 42: 1-18 (2020) https://doi.org/10.4178/epih.e2020007

28. Z. Wu, J. M. McGoogan. Characteristics of and important lessons from the Coronavirus Disease 2019 (COVID-19) outbreak in China: Summary of a report of 72314 Cases from the Chinese Center for Disease Control and Prevention. J. Am. Med. Assoc. 323 (13): 1239-42 (2020) https://doi.org/10.1001/jama.2020.2648

29. M. L. Holshue et al. First Case of 2019 Novel Coronavirus in the United States, N. 
Engl. J. Med. 382 (10): 929-36 (2020) https://doi.org/10.1056/NEJMoa2001191 